\title{
Sustainable Forest Management, FLEGT, and REDD+: Exploring Interlinkages to Strengthen Forest Policy Coherence
}

\author{
Yitagesu Tekle Tegegne ${ }^{1, *}$, Mathias Cramm ${ }^{2}$ and Jo van Brusselen ${ }^{2}$ \\ 1 European Forest Institute, St Pau Historical Site, St. Leopold Pavilion, c/St. Antoni M. Claret, 167, \\ 08025 Barcelona, Spain \\ 2 European Forest Institute, Yliopistokatu 6, 80100 Joensuu, Finland; m.cramm@gmail.com (M.C.); \\ jo.vanbrusselen@efi.int (J.v.B.) \\ * Correspondence: yitagesu.tekle@efi.int; Tel.: +34-667-527-202
}

Received: 3 September 2018; Accepted: 15 December 2018; Published: 18 December 2018

\begin{abstract}
Sustainable forest management (SFM) is a concept that guides forest management and policy globally. Over the past decades, two prominent regimes have emerged at the global level that can strengthen SFM: The European Union's Action Plan on Forest Law Enforcement, Governance, and Trade (FLEGT) and the United Nations' mechanism for reducing emissions from deforestation and forest degradation in developing countries, and the role of conservation, sustainable management of forests and enhancement of forest carbon stocks in developing countries (REDD+). However, the understanding of how FLEGT and REDD+ can interlink with SFM to strengthen forest policy coherence is limited. Enhancing knowledge about interlinkages and synergies is important in view of recent global commitments to strengthen policy coherence. This study employed content analysis of the main global policy documents related to FLEGT and REDD+ to identify (i) the potential contributions of the two regimes to SFM, and (ii) strategies to manage the interlinkages among SFM, FLEGT, and REDD+. The results revealed several potential interlinkages, such as monitoring, reporting, and verification systems, establishing the enabling conditions of SFM, and addressing drivers of forest degradation. However, the interlinkages must be managed if their potential is to be realized. For this, the study proposes three approaches to managing the interlinkages and catalyzing progress toward SFM.
\end{abstract}

Keywords: sustainable forest management; FLEGT; REDD+; policy coherence; synergies; interlinkage management

\section{Introduction}

The loss of tropical forests has spurred the development of a number of forums and instruments relevant to forests. These instruments include the Intergovernmental Panel on Forests (IPF), the Intergovernmental Forum on Forests (IFF), the United Nations Forum on Forests (UNFF), the Non-Legally Binding Instrument on All Types of Forests (NLBI), the International Tropical Timber Agreement, and several market-based forest certification schemes. All these instruments aim to achieve, among other objectives, sustainable forest management (SFM). SFM is perceived as a concept that balances the environmental, social, and economic objectives related to forests, to meet the needs of the present and future generations. The concept of SFM has evolved through an ongoing international forest policy dialogue, which has contributed to translating the concept into practice [1,2].

Over the past decade, two prominent regimes have emerged in support of SFM. The first is the European Union's (EU) Forest Law Enforcement, Governance, and Trade (FLEGT) Action Plan of 2003. It consists of supply side and demand side measures [3]. The supply side measure is 
Voluntary Partnership Agreements (VPAs) between the EU and the governments of non-EU timber producing and exporting countries. The key demand side measure is the EU Timber Regulation (EUTR), which places the responsibility for the legality on businesses that import timber and timber-related products into the EU (i.e., importers/suppliers). The second prominent regime is the United Nations Framework Convention on Climate Change (UNFCCC) "Reducing emissions from deforestation and forest degradation in developing countries, and the role of conservation, sustainable management of forests and enhancement of forest carbon stocks in developing countries" (REDD+). At the global level, the main organizations supporting REDD+ financially are the World Bank and the United Nations (UN). Their support, which began a decade ago, will likely continue for the foreseeable future, as both organizations have shown continued commitment to their REDD+ programs [4,5]. Additionally, the Green Climate Fund (GCF)—which forms the financial mechanism of the UNFCCC - is to provide substantial financing for REDD+, as participating developing countries progress to be eligible for results-based payments [6].

Some scholars claim that the REDD+ [7] and FLEGT [8,9] regimes have lost their momentum. However, the authors argue that the regimes remain relevant for the ongoing efforts toward the sustainable use and management of tropical forests for a number of reasons. "Political support for REDD+ is likely to be sustained, as avoiding deforestation is still perceived as a cheaper way of avoiding emissions than cutting the use of fossil fuels [ ... ]" [10]. In fact, "REDD+—despite all its shortcomings—is the only existing mechanism legitimized and recognized by all members of the UNFCCC" [10]. Due to its integration with Nationally Determined Contributions (NDCs), REDD+ has received increased longevity in the global policy arena for climate change mitigation [10]. Similarly, recent assessments have confirmed the continuing importance of FLEGT. These include an independent evaluation [11], a European Court of Auditors report [12], and the Council of the European Union's Conclusion on FLEGT [13]. Overall, these have commended the FLEGT Action Plan for its ongoing relevance. Evidence of enduring political support for FLEGT is indicated by the 2017 resolution adopted by the European Parliament that urged the EU "to maintain its commitments to step up ongoing negotiations on FLEGT Voluntary Partnership Agreements" [14]. Furthermore, in 2018, additional tropical countries-for example, Vietnam and Honduras-signed and concluded a VPA with the EU, respectively, while other countries are entering the negotiation phase. At the moment (December 2018), 15 tropical countries are negotiating and/or implementing REDD+ and FLEGT regimes.

The fact that the broad objectives of the SFM concept and FLEGT and REDD+ regimes are similar and that they are being implemented simultaneously in several tropical countries, raises the question whether and, if so, how they interlink with and complement one another $[15,16]$. Forest policy makers and practitioners have repeatedly called for this to be addressed $[17,18]$. However, this approach to regime interlinkages and policy learning is still poorly understood.

Previous studies have explored existing and potential interlinkages between FLEGT and REDD+ at national levels [19-25], REDD+ and the Sustainable Development Goals (SDGs) [15], and forests and the SDGs [26,27]. McDermott et al. [28] examined how various forest-relevant instruments and processes have shaped international forest policy and the holistic concept of SFM, although this analysis did not include FLEGT or REDD+. Furthermore, Cosslett [29] and Singer [30] studied the financing landscape relevant to SFM. However, no previous study has explicitly examined how SFM affects or is affected by such interlinkages [19] or identified strategies to manage the interlinkages among SFM, FLEGT, and REDD+ to strengthen forest policy coherence. Therefore, this study set out to answer the following research questions:

- What are the potential contributions of FLEGT and REDD+ to SFM, and how do the three interlink at a global policy level?

- How can the interlinkages between SFM, FLEGT, and REDD+ be managed to strengthen forest policy coherence, and what challenges stand in the way of realizing the interlinkages?

By addressing these questions, this paper contributes to the literature on interlinkages between forest governance regimes and to the emerging literature on interlinkage management and policy 
coherence. While the literature on FLEGT and REDD+ interlinkages at the national level is growing, such analysis at the global level is both a novelty and much needed. Outcomes at the global level give direction and momentum to regional and national forest policy making and implementation. Moreover, the analysis is especially timely, as the momentum toward SFM and policy coherence has recently been catalyzed by important global policy developments. These include the SDGs, the United Nations Strategic Plan for Forests (UNSPF), the Paris Agreement on climate change, and the International Arrangement on Forests beyond 2015 [31]. The authors argue that understanding and recognizing how FLEGT and REDD+ interlink with SFM is a first step toward actively managing the interlinkages and enhancing forest policy coherence.

While the authors recognize the presence of several related terms in the literature (e.g., synergy, interaction, linkage, overlap), this study adopts the term "interlinkage" to denote connectedness between overlapping or related regimes, namely the interlinkages between SFM, FLEGT, and REDD+.

The rest of this paper is structured as follows: Section 2 introduces the methodology, including the analytical framework. Section 3 presents the results, while Section 4 discusses some of the key findings. Finally, Section 5 draws conclusions and makes recommendations.

\section{Methodology}

In this section, we (i) define the holistic concept of SFM, (ii) introduce the analytical framework, and (iii) present the review approach, including data sources and the method of analysis.

\subsection{Introducing the Holistic Concept of SFM}

Since the 1992 non-legally binding authoritative statement of principles for a global consensus on the management, conservation, and sustainable development of all types of forests (Forest Principles), the understanding of SFM at the global level has confirmed that the concept embodies-with equal weighting-multiple values, such as social, economic, ecological, cultural, and spiritual values [32]. The concept of SFM has been framed as a principle to follow or respect, and as an objective to achieve [11,33,34], namely that all types of forests should be managed sustainably. Key policy developments relevant to SFM are shown in a timeline in Figure 1. Various definitions of SFM have been developed, reflecting how SFM has a different meaning for different people, even at different times.

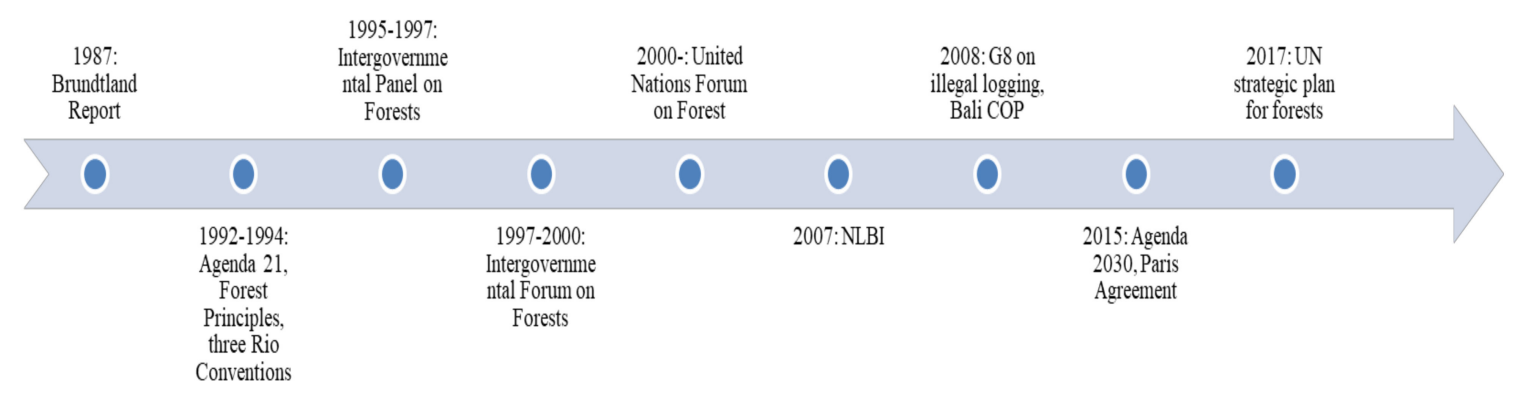

Figure 1. Timeline of key policy developments relevant to sustainable forest management since 1987.

The UN define SFM as "[A] dynamic and evolving concept, [that] aims to maintain and enhance the economic, social, and environmental values of all types of forests, for the benefit of present and future generations." [35]. while not particularly strong, highlights the dynamic and evolving nature of the concept. Thus, it is likely not possible to objectively and universally state what "sustainability" actually means in forest management, since that understanding is affected by space, time, new knowledge, and the changing valuation of forests by people [36]. Nevertheless, catalyzed by the outcomes of the UN Conference on Environment and Development in 1992, various regional and international Criteria and Indicators (C\&I) processes have been aimed at sharpening the concept in order to be able to guide and measure concrete progress toward SFM and, thus, further define what the 
concept entails [36]. The application of regional approaches demonstrates how SFM has been framed varyingly in different contexts [36].

In 1994, the FAO conducted an overview of various C\&I processes and found six common elements that characterize SFM: (i) Extent of forest resources; (ii) conservation of biological diversity; (iii) forest health and vitality; (iv) productive functions of the forest; (v) protective functions of the forest; and (vi) forest-related economic and social needs [37]. A seventh criterion from the Montreal C\&I process concerning the policy and legal framework and capacity to implement SFM was also recognized [37]. Similar characterizations have since been done and acknowledged by the International Conference on the Contribution of C\&I for SFM in 2003 [38], the FAO Committee on Forestry in 2003 [39], the FAO/ITTO expert consultation on C\&I for SFM in 2004 [40], and the Collaborative Partnership on Forests Task Force on Streamlining Forest-Related Reporting in 2004 [41]. In 2007, the UNFF endorsed the seven thematic elements of SFM [41]. It defined the seven elements as:

1. Extent of forest resources;

2. Forest biological diversity;

3. Forest health and vitality;

4. Productive functions of forest resources;

5. Protective functions of forest resources;

6. Socioeconomic functions of forests; and

7. Legal, policy, and institutional framework.

Roughly speaking, the first element refers to the quantity of forest, and elements two to six refer to the quality of forest and the wide range of ecosystem services and associated benefits that they provide. The last element describes the enabling conditions that underlie the other elements.

These seven thematic elements capture the environmental, social, economic, and governance dimensions related to SFM in a way that characterizes, in a broad sense, the various issues to be considered when assessing the sustainability of forest management and measuring progress toward SFM. This thematic characterization is what embodies the holistic concept of SFM. Sometimes, SFM is defined and understood as the management of forest for sustainable production. However, the holistic concept of SFM goes beyond that and is not limited to or dependent on any administratively designated function of a forest. Instead, it presents a broad framework against which any and all forests can be characterized. As such, the authors see the holistic concept of SFM with its seven elements as related to and building on the UN definition of SFM by giving it definitional clarity.

The strength of the thematic focus is that it enables the identification of which areas matter to and define sustainability in forest management, without necessitating the specification of measurable indicators. However, the seven elements lack a more precise thematic definition, as neither UNFF nor any other internationally recognized body has elaborated on their contents. The following section operationalizes the elements to allow their utilization in assessing the contribution of FLEGT and REDD+ to SFM, and the potential interlinkages therein.

\subsection{Analytical Framework}

Over the last three decades, international regimes have been the subject of intense interest within the scientific community [42] and among policy makers. While the authors recognize both broad [43,44] and narrow [45] definitions of a regime, this paper adopts the narrow view that conceptualizes a regime as a single international agreement. From this view, each of the different international agreements on forests, such as FLEGT, NLBI, and REDD+, can be treated as independent and different forest regimes. Visseren-Hamakers et al. [46] argue that this narrow view is particularly useful when one is interested in analyzing interlinkages between two or more international regimes.

There is an abundance of frameworks and typologies in the literature that facilitate the analysis of interlinkages between regimes, such as the concepts of regime interactions [47], social network analysis [48], and the typology of fragmentation of global governance architectures [49]. 
Interactions between regimes could lead to three different consequences: Synergy, conflict, and neutral (for detailed discussions on the consequences of regime interactions, see also [47,50]). Gehring and Oberthür [47] and van Asselt [50] argue that before examining the interlinkages and trade-offs, the potential and existing contributions of one regime to another need to be identified and established. To that end, this study employed the seven thematic elements of SFM as a basis to analyze the contributions of FLEGT and REDD+ to the holistic concept of SFM, and thereby to identify the interlinkages between SFM, FLEGT, and REDD+. The objective was to develop a streamlined framework that captures the core thematic issues (which this study calls "sub-topics") under each SFM element, without ending up with too many sub-topics and an overly complicated framework.

Various scholars have employed the seven elements of SFM as a conceptual framework to assess the contributions of different forest-related instruments to SFM [28], to analyze the potential impacts of REDD+ on the achievement of SFM [29], to evaluate different management practices [51], and to identify criteria and indicators [52]. Due to its relative detail and comprehensiveness, the present study adopted the initial framework developed by McDermott et al. [28], and reformulated and enriched it to capture recent developments relevant to the holistic concept of SFM and to the internationally agreed goals and commitments related to SFM. As a result, some sub-topics were merged and/or reformulated, while others were omitted from the initial framework of McDermott et al. [28]. The omitted sub-topics include biodiversity (ecosystem), biodiversity (species), impacts of pollution, impacts of climate change, biotech risks, pollution mitigation, general socioeconomic benefit, non-consumptive/recreational use, multilateral legal frameworks, multilateral policy frameworks, and multilateral institutional frameworks.

The resulting analytical framework was enriched by introducing certain aspects from the recent literature on sustainable natural resources management [1,2,53-55]. For instance, the International Tropical Timber Organization (ITTO) [53] enhanced the initial framework by introducing forest resilience, and ITTO [53] and the UN [56] broadened it by incorporating forest product traceability systems and independent compliance schemes. Furthermore, Kleinschmit et al. [54] and Seppälä et al. [55] reinforced our framework by introducing climate change adaptation and legality/illegality in production, processing, and trade, which are absent from the initial framework of McDermott et al. [28]. Table 1 presents the framework with the seven thematic elements of SFM and the sub-topics (for detailed definitions of the elements and sub-topics, see the Appendix A).

Table 1. Operationalization of the seven thematic elements of SFM into sub-topics.

\begin{tabular}{|c|c|c|}
\hline Seven Elements of SFM & Sub-topics & Source \\
\hline \multirow{3}{*}{ 1. Extent of forest resources } & 1.1 Inventory and data & [28] \\
\hline & 1.2 Afforestation and reforestation & [28] \\
\hline & 1.3 Deforestation & [28] \\
\hline \multirow{3}{*}{ 2. Forest biological diversity } & 2.1 Biodiversity & [28] \\
\hline & 2.2 Biodiversity (genetic) & [28] \\
\hline & 2.3 Protected areas & {$[28,56]$} \\
\hline \multirow{3}{*}{ 3. Forest health and vitality } & 3.1 Natural disturbances and forest resilience & {$[28,53]$} \\
\hline & 3.2 Forest degradation & [28] \\
\hline & 3.3 Rehabilitation/restoration & {$[28,53]$} \\
\hline \multirow{3}{*}{ 4. Productive functions of forest resources } & 4.1 Forest productivity & {$[28,53]$} \\
\hline & 4.2 Accounting & {$[28,53]$} \\
\hline & 4.3 Forest product traceability systems & {$[53,56]$} \\
\hline \multirow{4}{*}{ 5. Protective functions of forest resources } & 5.1 Carbon and climate change mitigation & [28] \\
\hline & 5.2 Climate change adaptation & [55] \\
\hline & 5.3 Desertification and land degradation & [28] \\
\hline & 5.4 Soil and water & {$[28,53,56]$} \\
\hline
\end{tabular}


Table 1. Cont.

\begin{tabular}{clc}
\hline \multicolumn{1}{c}{ Seven Elements of SFM } & \multicolumn{1}{c}{ Sub-topics } & Source \\
\hline & 6.1 Economic development & {$[28,56]$} \\
& 6.2 Legality/illegality in production, processing, and trade & {$[54]$} \\
& 6.3 Local benefit and wellbeing & {$[28,53,56]$} \\
6. Socioeconomic functions of forests & 6.4 Resource rights & {$[28,53]$} \\
& 6.5 Traditional knowledge and use & {$[28,53]$} \\
& 6.6 Public participation & {$[28,53]$} \\
\hline \multirow{3}{*}{ 7. Legal, policy and institutional framework } & 7.1 Capacity transfer & {$[28,53,56]$} \\
& 7.2 Country-level legal, policy, and institutional frameworks & {$[28,53,56]$} \\
& 7.3 Independent compliance schemes & {$[53,56]$} \\
\hline
\end{tabular}

Scholars have employed different terms—such as synergy [57], interplay [58], interaction [47], overlap [59], and interlinkage [60] — to denote the connectedness between overlapping regimes [50]. The difference between the terms is blurry. To avoid misunderstanding, we adopted the term "interlinkage," which denotes the connectedness among regimes that is rooted in their mere existence. Thus, simply the presence of regimes can trigger interlinkages among them. This fits the focus of this study on the global policy level, rather than on on-the-ground implementation of SFM, FLEGT, and REDD+.

\subsection{Review Approach}

Considering the global scale of assessment in this study, the sources chosen also focus on the global level. There are several legally binding and non-legally binding instruments that define the FLEGT and REDD+ regimes, and an effort was thus made to identify associated policy documents relevant to defining and shaping the global/general architectures of the said regimes (Table 2). This is because SFM, as a dynamic and evolving concept, is constantly changing and the global domain formed by the global instruments relevant to forests can have a significant influence on the concept [2]. Outcomes at the global level give direction and momentum to regional and national forest policy making and implementation. The key policy documents relevant to FLEGT and REDD+ are presented in Table 2. Although the FLEGT Action Plan has seven components [3], only policy documents related to components concerning (i) support to timber-producing countries and (ii) trade in timber were considered in this study. This paper does not provide an analysis of the remaining components of the Action plan nor national regulatory frameworks, which usually describe numerous elements of SFM in a country context.

Table 2. Overview of key policy documents reviewed.

\begin{tabular}{|c|c|c|c|}
\hline Document Title & Prepared by & Publication Year & Reference \\
\hline \multicolumn{4}{|c|}{ FLEGT Related Policy Documents } \\
\hline $\begin{array}{l}\text { Forest Law Enforcement Governance and Trade, proposal } \\
\text { for an Action Plan }\end{array}$ & European Commission & 2003 & [3] \\
\hline $\begin{array}{c}\text { Council conclusions on Forest Law Enforcement, } \\
\text { Governance, and Trade (FLEGT) }\end{array}$ & European Council & 2003 & {$[61]$} \\
\hline FLEGT Briefing Notes 1-8 & European Commission & 2007 & [62] \\
\hline
\end{tabular}


Table 2. Cont.

\begin{tabular}{|c|c|c|c|}
\hline Document Title & Prepared by & Publication Year & Reference \\
\hline \multicolumn{4}{|c|}{ REDD+ related policy documents } \\
\hline $\begin{array}{l}\text { Report of the Conference of the Parties on its thirteenth } \\
\text { session, held in Bali from } 3 \text { to } 15 \text { December } 2007\end{array}$ & UNFCCC & 2007 & [63] \\
\hline $\begin{array}{l}\text { Report of the Conference of the Parties on its fifteenth } \\
\text { session, held in Copenhagen from } 7 \text { to } 19 \text { December } 2009\end{array}$ & UNFCCC & 2009 & [64] \\
\hline $\begin{array}{l}\text { Report of the Conference of the Parties on its sixteenth } \\
\text { session, held in Cancun from } 29 \text { November to } \\
10 \text { December } 2010\end{array}$ & UNFCCC & 2010 & [65] \\
\hline $\begin{array}{l}\text { Report of the Conference of the Parties on its nineteenth } \\
\text { session, held in Warsaw from } 11 \text { to } 23 \text { November } 2013\end{array}$ & UNFCCC & 2013 & [66] \\
\hline $\begin{array}{l}\text { Report of the Conference of the Parties on its twenty-first } \\
\text { session, held in Paris from } 30 \text { November to } \\
13 \text { December } 2015\end{array}$ & UNFCCC & 2015 & [67] \\
\hline FCPF Carbon Fund Methodological Framework & FCPF & 2016 & [4] \\
\hline $\begin{array}{l}\text { Terms of reference for the pilot programme for REDD+ } \\
\text { results-based payments }\end{array}$ & GCF & 2017 & {$[68]$} \\
\hline
\end{tabular}

The policy documents identified in Table 2 were subjected to a content analysis to investigate the potential contributions of FLEGT and REDD+ to the various sub-topics. The method of content analysis is useful when the focus is on investigating, for example, the origin and operation of a program, such as a policy [69]. The potential contributions were examined by identifying explicit excerpts of text referring to the sub-topics. However, a certain degree of flexibility in terms of "reading between the lines" was adopted to establish connections that might have otherwise gone unobserved. Furthermore, preambles were excluded from the analysis. It should also be noted that the analysis was done not to reveal actual or existing on-the-ground contributions of FLEGT and REDD+ to the various thematic SFM areas, but to examine these contributions (and thereby interlinkages between SFM, FLEGT, and REDD+) at the global policy level.

A three-point Likert scale was used to determine the degree of contribution by FLEGT/REDD+ to SFM sub-topics as follows:

(i) Direct contribution, when a sub-topic was given explicit consideration, for example, in the form of policy tools, objectives, or activities to achieve the objectives;

(ii) Indirect contribution, when a sub-topic was not given explicit consideration, but when policy tools, objectives, or activities to achieve the objectives can nevertheless have an impact on the sub-topic; and

(iii) No contribution, when a sub-topic was not given explicit consideration and policy tools, objectives, and activities to achieve the objectives cannot be expected to have an impact on the sub-topic.

\section{Potential Contributions of FLEGT and REDD+ to the Holistic Concept of SFM}

In this section, we present the main contributions of the FLEGT and REDD+ regimes to SFM, and the interlinkages among the three. Table 3 summarizes the analysis by showing the contribution of FLEGT and REDD+ to SFM and is followed by more specific results. 
Table 3. Contribution of FLEGT and REDD+ to the sub-topics in the holistic concept of SFM.

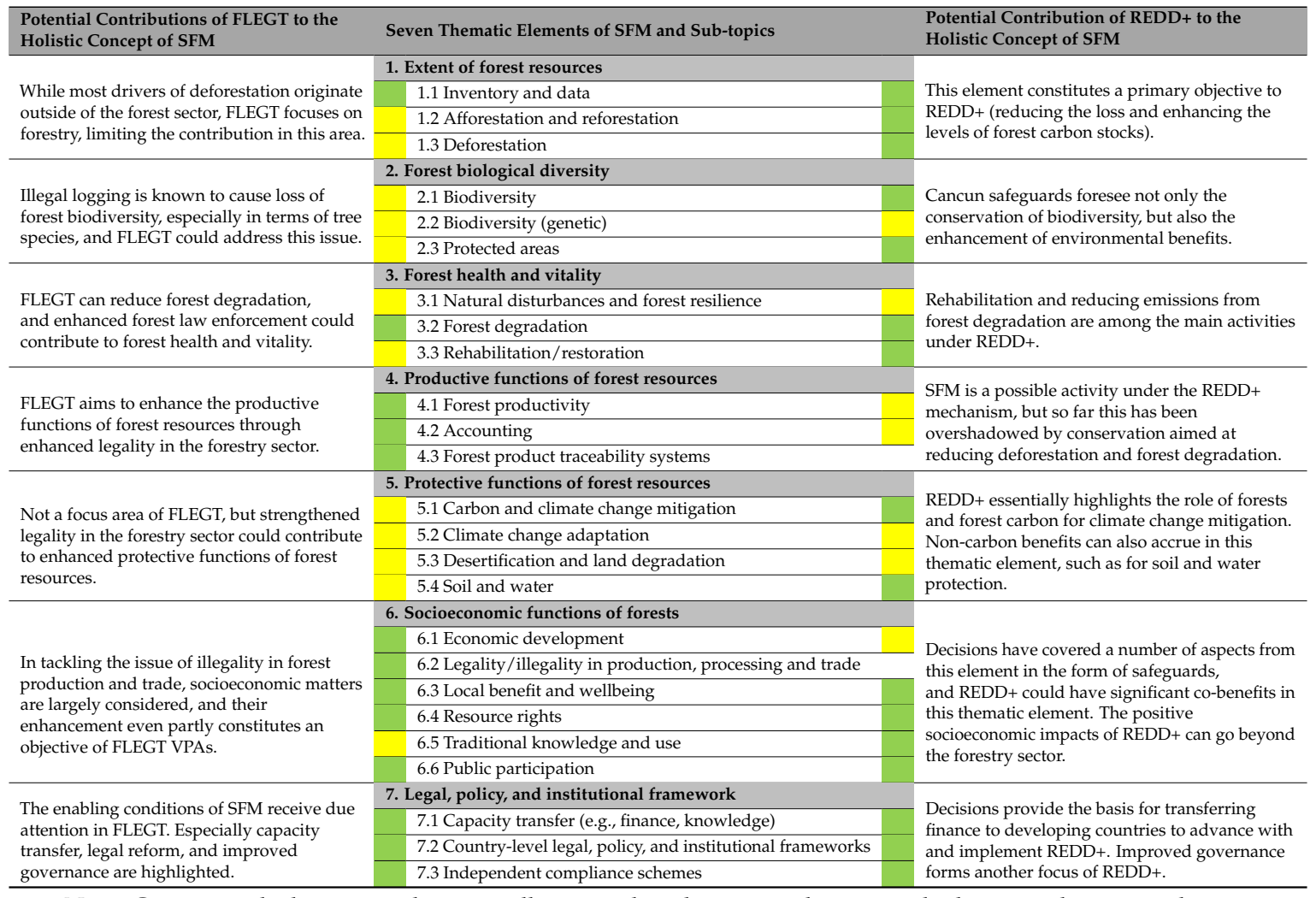

Note: Green signals direct contribution, yellow signals indirect contribution, and white signals no contribution.

SFM elements and sub-topics are defined in the Appendix A; the three categories of contributions are clarified in

Section 2.3.

\subsection{SFM Element \#1-Extent of Forest Resources}

\section{Sub-topic 1.1-Inventory and data}

FLEGT, direct contribution: Enhanced forest law enforcement under FLEGT VPA foresees the development of and adherence to forest management plans, including forest resource inventories at the forest management unit level, which produces detailed information on the extent and structure of forest resources as well as information on non-timber forest products. Inventories form an important part of the timber legality assurance systems (TLAS) of FLEGT VPAs. TLAS and associated inventories and commitments provide information about, inter alia, the allocation of timber concessions and contracts, taxes, management plans, and demonstration of sincere efforts for sustainable forest management.

REDD+, direct contribution: REDD+, as per decisions 4/CP.15 and 1/CP.16, requires countries to develop national forest monitoring systems (NFMSs), including measuring, reporting, and verification (MRV) functions, whereby the focus is on estimating levels of carbon $[64,65]$. The REDD+ MRV will generate significant amounts of information about, inter alia, the extent and condition of forest, land use, and land-use changes, and the social, environmental, and governance benefits.

\section{Sub-topic 1.2-Afforestation and reforestation}

FLEGT, indirect contribution: Many forest countries include environmental requirements in their legal framework to ensure adherence to certain management practices, such as enrichment planting, tree planting, afforestation, and buffer zones. FLEGT, by improving the enforcement of such legal requirements in the forest sector, could indirectly contribute to reforestation and afforestation activities.

REDD+, direct contribution: In the case of REDD+, "enhancement of forest carbon stocks" is an acknowledged activity for which a country can be financially rewarded [65].

\section{Sub-topic 1.3-Deforestation}

FLEGT, indirect contribution: FLEGT does not directly or explicitly address deforestation and is more focused on illegal logging as a driver of forest degradation. However, degraded forests can be 
more likely to be deforested or converted to non-forest uses [70,71], so through enhanced control of illegal logging and forest degradation, FLEGT can aid in reducing deforestation [13,25].

REDD+, direct contribution: REDD+ defines deforestation as one of its core issues and targets direct drivers and underlying causes of deforestation both within and outside the forestry sector [65].

\subsection{SFM Element \#2-Forest Biological Diversity}

\section{Sub-topic 2.1-Biodiversity}

FLEGT, indirect contribution: Illegal logging is often focused on the commercially most valuable tree species, which can lead to their overharvesting and even sectional extinction [72]. In addition, poaching — which is associated with illegal logging-can have significant negative impacts on forest wildlife [73]. Therefore, although the issue is not given explicit consideration, improved legality and forest law enforcement catalyzed by FLEGT can aid in the conservation of biodiversity.

REDD+, direct contribution: REDD+ has a specific safeguard on biodiversity (Cancun safeguard e), according to which actions should be "consistent with the conservation of natural forests and biological diversity" and "enhance other social and environmental benefits" [65]. Such considerations are also taken into account in the GCF pilot program for REDD+ results-based payments, with a requirement to comply with GCF policy on Environmental Safeguards [68].

Sub-topic 2.2-Biodiversity (genetic)

FLEGT and REDD+, indirect contribution: Neither FLEGT nor REDD+ have provisions on genetic diversity or appear to specifically promote its conservation or enhancement. However, genetic diversity could be impacted by the broader biodiversity measures.

\section{Sub-topic 2.3-Protected areas}

FLEGT, indirect contribution: FLEGT aims to address illegal logging, whether it takes place, for instance, "openly" in forest concessions or more covertly in national parks [3]. Thus, FLEGT can eliminate market opportunities for illegally harvested timber originating from protected areas.

REDD+, direct contribution: An environmental safeguard under REDD+ (Cancun safeguard e) states that actions undertaken should be used to "incentivize the protection and conservation of natural forests and their ecosystem services" [65].

\subsection{SFM Element \#3-Forest Health and Vitality}

\section{Sub-topic 3.1-Natural disturbances and forest resilience}

FLEGT, indirect contribution: Natural disturbances to forests, such as alien species, fire, pests, and disease, are not explicitly addressed by FLEGT or REDD+. However, FLEGT, through enhanced law enforcement, can bring about better forest management and reduced forest degradation, both of which can reduce the risk of such natural disturbances occurring, and increase forest resilience.

REDD+, indirect contribution: REDD+ may address natural disturbances as drivers of forest degradation that can also enhance forest resilience, but this is dependent on associated national policies and measures.

\section{Sub-topic 3.2-Forest degradation}

FLEGT, direct contribution: Forest degradation is driven by illegal logging [74], the halting of which is the ultimate objective of FLEGT.

REDD+, direct contribution: Reducing forest degradation counts as an activity under the REDD+ mechanism [65].

\section{Sub-topic 3.3-Rehabilitation/restoration}

FLEGT, indirect contribution: Under improved forest law enforcement, efforts to rehabilitate/restore logged-over forests can be expected to be strengthened.

REDD+, direct contribution: Rehabilitation/restoration can count as an activity under the REDD+ mechanism [65], as it enhances carbon capture. 


\subsection{SFM Element \#4-Productive Functions of Forest Resources}

\section{Sub-topic 4.1-Forest productivity}

FLEGT, direct contribution: FLEGT has a strong link to forest productivity [3]. FLEGT, by enhancing forest law enforcement, can directly contribute to more sustainable logging practices, such as reduced impact logging (RIL), and generally influence the way in which forests are managed. The TLAS of VPAs are key tool in this regard [75].

REDD+, indirect contribution: REDD+, as it includes SFM as an eligible activity [65], could specifically incentivize the adoption of RIL over conventional logging, as SFM projects under REDD+ could in this way benefit from reduced emissions from forest management and logging [76-78].

\section{Sub-topic 4.2-Accounting}

FLEGT, direct contribution: FLEGT can promote the inclusion of various data in forest productivity and management. Better forest law enforcement can, for instance, ensure that environmental and social impact assessments related to logging operations are conducted and that the necessary data related to timber production, processing, and trade (e.g., harvest reports, timber export files) are produced.

REDD+, indirect contribution: REDD+ has the potential to highlight the role of carbon data in forest management planning and implementation [77]. Furthermore, all REDD+ safeguards, including social and environmental considerations, need to be taken into account and respected when undertaking eligible activities, such as SFM [65].

\section{Sub-topic 4.3-Forest product traceability systems}

FLEGT, direct contribution: Systems that are able to trace wood and wood products back to their geographic origin, and distinguish between legal and illegal timber, are a key aspect of FLEGT VPAs [3].

REDD+, no contribution: REDD+ does not contain provisions on this issue. REDD+ MRV systems would, however, benefit from the inclusion of traceability data on timber removals.

\subsection{SFM Element \#5-Protective Functions of Forest Resources}

\section{Sub-topic 5.1-Carbon and climate change mitigation}

FLEGT, indirect contribution: FLEGT can reduce levels of forest degradation and accelerate the adoption of improved and more sustainable logging practices, such as RIL, both of which can support climate change mitigation [79].

REDD+, direct contribution: REDD+ essentially aims to reinforce the role of forests and the carbon stored therein for climate change mitigation [e.g., 63].

\section{Sub-topic 5.2-Climate change adaptation}

FLEGT, indirect contribution: Although climate change adaptation is not a stated objective or an intended impact of FLEGT, FLEGT can support improved forest health and vitality, which in turn can enhance the role of forests in national strategies and policies for climate change adaptation.

REDD+, indirect contribution: While the objective of REDD+ is explicitly related to climate change mitigation and the mechanism does not directly reward activities related to adaptation, REDD+ can also strengthen the role of forests in climate change adaptation through more extensive forest cover in a country, and the mitigation activities can support adaptation.

\section{Sub-topic 5.3-Desertification and land degradation}

FLEGT and REDD+, indirect contribution: Especially, forests in drylands play an important role in combatting desertification and land degradation [80]. Yet FLEGT could, for instance, prevent illegally logged timber from dryland forests from entering markets. REDD+ could protect dryland forests by addressing associated drivers of forest loss [80].

\section{Sub-topic 5.4-Soil and water}

FLEGT, indirect contribution: The attention that FLEGT pays to logging is also relevant to the protective functions of forests for soil and water. Essentially, legal and environmentally integral forest management can support the conservation and protection of soil and water that might otherwise be negatively impacted by illegal logging. 
REDD+, direct contribution: Soil and water protection can be considered as non-carbon benefits under REDD+ and these values, according to the REDD+ safeguards policy (Cancun safeguard e), should be protected, conserved, and enhanced [65]. Reducing the loss and enhancing the levels of forest carbon stocks can support these objectives.

\subsection{SFM Element \#6-Socioeconomic Functions of Forests}

\section{Sub-topic 6.1-Economic development}

FLEGT, direct contribution: Promoting the legal trade in timber products is a stated objective in the VPAs, which cover international trade and, in most cases, domestic markets. This is linked with the wider objectives of economic growth, industrial wood production, and the associated employment. Improved forest law enforcement also has implications for the collection rates of related taxes and levies [81].

REDD+, indirect contribution: Economic development in connection with REDD+ is more related to local-level benefits and livelihoods rather than nationwide economic growth. It could, however, be beneficial to a successful REDD+ implementation if sustainable economic development were explicitly considered amongst policy objectives. This is because REDD+ could also support the sustainable management and use of ecosystem services other than wood [82].

Sub-topic 6.2-Legality/illegality in production, processing, and trade

FLEGT, direct contribution: FLEGT essentially targets this sub-topic [83], and legal requirements for forest management are understood as the basis for SFM [13].

REDD+, no contribution: REDD+ does not explicitly address the question of legality in production, processing, and trade.

\section{Sub-topic 6.3-Local benefit and wellbeing}

FLEGT, direct contribution: VPAs incorporate social safeguards to minimize possible adverse impacts on local and indigenous communities [84]. Moreover, enhanced legality in the industrial logging sector can contribute to more equitable and effective benefit sharing with local communities [85,86].

REDD+, direct contribution: REDD+ safeguards policy (Cancun safeguards $\mathrm{c}$ and d) also aims to protect local people from possible adverse impacts resulting from the implementation of REDD+ activities, and it is generally acknowledged that REDD+ has high relevance to local wellbeing, livelihoods, and poverty reduction through non-carbon benefits and benefit sharing $[65,87,88]$. Also, the GCF in its pilot program for REDD+ results-based payments calls for an assessment describing "the extent to which the measures undertaken to identify, assess, and manage [ ... ] social risks and impacts, in the context of the REDD+ proposal, were consistent with the requirements of the applicable GCF Environmental and Social Safeguard standards" [68].

\section{Sub-topic 6.4-Resource rights}

FLEGT, direct contribution: The European Council [61] conclusions on FLEGT highlighted that VPAs should "strengthen land tenure and access rights especially for marginalized, rural communities and indigenous peoples." FLEGT, through improved governance and law enforcement, can have an important role in clarifying and strengthening the tenure rights of both private forest operators and local and indigenous communities who, for instance, live in or near forest concessions $[11,13,72]$.

REDD+, direct contribution: REDD+ has incorporated a safeguard specifically calling for respect for the rights of indigenous peoples and members of local communities (Cancun safeguard c) [65]. REDD+ policies at the national level need to clarify tenure rights to determine the potential beneficiaries of the mechanism [89-91].

\section{Sub-topic 6.5-Traditional knowledge and use}

FLEGT, indirect contribution: Although traditional knowledge is not mentioned, VPAs' social safeguard clause foresees the development of a better understanding of the livelihoods of potentially affected indigenous and local communities [84]. This becomes relevant when forest law enforcement and the legalization of forest production could negatively affect local populations and their 
forest-related livelihoods [11]. However, the safeguard aims to minimize possible adverse impacts, not to enhance associated social values.

REDD+, direct contribution: REDD+ safeguard policy (Cancun safeguard c) calls for respect for the knowledge and rights of indigenous peoples and members of local communities [65]. It has also been recognized that to address issues related to the coordination of support for REDD+ activities, the sharing of relevant information, knowledge, experiences, and good practices at the international level-taking into account national experiences and, as appropriate, traditional knowledge and practices—-needs to be strengthened, consolidated, and enhanced [66].

\section{Sub-topic 6.6-Public participation}

FLEGT, direct contribution: The FLEGT Action Plan [3] and the European Council [61] conclusions on FLEGT require the effective participation of stakeholders, including local communities and indigenous peoples, other non-state actors, and the private sector, in policy design and implementation. Stakeholder participation is also included as an article in VPAs [84].

REDD+, direct contribution: Under REDD+, the "full and effective participation of relevant stakeholders, in particular indigenous peoples and local communities" is safeguarded (Cancun safeguard d) [65]. Moreover, countries willing to participate in the GCF pilot program for REDD+ results-based payments will have to demonstrate their compliance with GCF policies, including on stakeholder engagement, which shall "include a description of how the stakeholders were identified, informed, and consulted and how they have participated in the activities" [68]. At the same time, local participation can also take the role of a non-carbon benefit [92].

\subsection{SFM Element \#7-Legal, Policy, and Institutional Framework}

\section{Sub-topic 7.1-Capacity transfer}

FLEGT, direct contribution: The FLEGT Action Plan sets the foundation for providing various types of support to partner countries to assist in FLEGT-related issues. For example, the need for capacity building in partner countries toward stronger institutions at the national level is recognized, and the European Commission is to provide development cooperation assistance "to strengthen developing country capacity to deal with forest-related money laundering issues" [3]. Furthermore, the European Commission is to provide support for "capacity building in developing countries to initiate private sector initiatives, for example in forest monitoring" [3].

REDD+, direct contribution: For REDD+, several decisions have tackled capacity transfer. For instance, decision 1/CP.16 urges Parties, in particular developed country Parties, to "support, through multilateral and bilateral channels, the development of national strategies or action plans, policies and measures and capacity-building, followed by the implementation of national policies and measures and national strategies or action plans that could involve further capacity-building, technology development and transfer and results-based demonstration [ ... ]" [65]. Decision 1/CP.21 has emphasized the importance of finance and positive incentives for REDD+ [67]. Ultimately, the REDD+ mechanism relies on the notion of financial rewards from developed to developing countries.

Sub-topic 7.2-Country-level legal, policy, and institutional frameworks

FLEGT, direct contribution: The FLEGT Action Plan recognizes the need for legal and policy reforms at the national level; for example, the national legal frameworks should set the premise for SFM [3]. By aiming to increase transparency in timber producing countries, FLEGT also tackles the issue of corruption, and the independent auditing of the VPAs' TLAS provides credibility to the whole system $[11,13,75,93]$. Moreover, developing institutional capacities and administrative systems in partner countries is a focus, as these countries are expected to ensure forest law enforcement and the monitoring of forestry activities.

REDD+, direct contribution: REDD+, likewise, has an explicit focus on the sub-topic. According to decision 1/CP.16, developing countries are to develop a national strategy or action plan for REDD+, as well as a safeguards information system for providing information on how the various safeguards 
are addressed and respected throughout the implementation of REDD+ activities [65]. The same decision also provides a safeguard (Cancun safeguard $b$ ) for transparent and effective national forest governance structures. As REDD+ can address drivers of deforestation and forest degradation beyond the forestry sector, it has the potential to influence policy, legal, and institutional coordination across sectors [94].

\section{Sub-topic 7.3-Independent compliance schemes}

FLEGT, direct contribution: The FLEGT Action Plan recognizes that "certification of sustainable forest management can [ ... ] act as a means of proof of compliance with [ ... ] environmental requirements and increase the likelihood that the public authority is being supplied with legally harvested timber" [3]. Furthermore, the essence of the EU's support is to promote the revision of and compliance with national regulatory frameworks in countries participating in FLEGT VPA. Because national regulatory frameworks usually describe numerous elements of SFM in a country context, a VPA can directly contribute to many of the SFM elements.

REDD+, direct contribution: The forest reference emission levels and/or forest reference levels for REDD+ submitted to the UNFCCC must undergo an independent technical assessment [66]. Furthermore, the FCPF Carbon Fund Methodological Framework requires the periodic auditing of the operation of national or centralized REDD+ programs by an independent third party [4].

Overall, the main potential contributions of FLEGT are in the following SFM elements: \#4 productive functions of forest resources (direct contribution to all sub-topics), \#6 socioeconomic functions of forests (direct contribution to all but one sub-topic), and \#7 legal, policy, and institutional framework (direct contribution to all sub-topics). This finding mostly corroborates earlier studies that reported that FLEGT (VPAs) had succeeded in improving public policy-making, participation, and forest governance in tropical timber producing countries $[11,95,96]$.

Our analysis also revealed that the main potential contributions of REDD+ are in SFM elements, $\# 1$ extent of forest resources (direct contribution to all sub-topics), \#2 forest biological diversity (direct contribution to all but one sub-topic), \#3 forest health and vitality (direct contribution to all, but one sub-topic), \#6 socioeconomic functions of forests (direct contribution to all, but two sub-topics), and \#7 legal, policy, and institutional framework (direct contribution to all sub-topics). This analysis resonates with the findings of Cosslett [29] and Long [97].

Various interlinkages arise from the individual contributions by FLEGT and REDD+ to the holistic concept of SFM. In the following sub-topics, both regimes made a direct contribution: 1.1 (inventory and data), 3.2 (forest degradation), 6.3 (local benefit and wellbeing), 6.4 (resource rights), 6.6 (public participation), 7.1 (capacity transfer), 7.2 (country-level legal, policy, and institutional frameworks), and 7.3 (independent compliance schemes).

\section{Discussion}

In this section, we discuss the interlinkages among SFM, FLEGT, and REDD+, the main challenges in realizing the synergies, and strategies to manage the interlinkages for enhanced forest policy coherence.

\subsection{Interlinkages}

Our analysis shows that FLEGT and REDD+ contribute to a number of identic SFM elements, namely SFM elements, \#6 (socioeconomic functions of forests) and \#7 (legal, policy, and institutional framework), as well as sub-topics, 1.1 (inventory and data), 3.2 (forest degradation), and 7.3 (independent compliance schemes). These elements and sub-topics thus constitute important interlinkages among SFM concept and FLEGT, and REDD+ regimes. For example, FLEGT (through VPA TLAS) and REDD+ (through NFMSs and MRV functions) contribute directly to sub-topic 1.1 (inventory and data). TLAS, among others, produces data on standing timber in and wood removals from forests. NFMS generates inventory data on forest carbon stocks and net emissions or removals. Therefore, TLAS and NFMS offer great potential for harmonized forest information 
collection, storage, and analysis [98]. This is in line with recent global efforts to harmonize forest-related data and understanding as indicated by target 6.4 UNSPF and the development of the GCS $[56,99]$. Thus, harmonizing inventory and data-related aspects among SFM, FLEGT, and REDD+ could contribute to such global efforts and to policy coherence.

The observed interlinkages among SFM, FLEGT, and REDD+ can be attributed to overlapping core norms and principles, as well as the supporting measures of FLEGT and REDD+. Both FLEGT and REDD+ have several non-conflicting requirements and principles, such as the principles of social and environmental safeguards, market incentives, SFM, capacity building of various stakeholders, multi-stakeholder consultation, awareness raising, and a credible, measurable, reportable, and verifiable system [16].

Our analysis also revealed that FLEGT and REDD+ contribute to different SFM elements. While FLEGT could mainly contribute to SFM element \#4 (productive functions of forest resources), REDD+ could contribute to SFM elements, \#1 (extent of forest resources), \#2 (forest biological diversity), and \#3 (forest health and vitality). The differences found in this study can be attributed to the differences in the focus of FLEGT and REDD+. The primary focus of FLEGT is to strengthen legality with the key assumption that clarity (and non-contestation) in legal frameworks forms the basis for sustainability, whereas REDD+ has a broader focus with the second D linked to forest degradation, and the + linked to the enhancement of forest carbon stocks, which speak more directly to the benefits from SFM in REDD+, and vice versa.

\subsection{Challenges to Realizing the Interlinkages}

Despite the potential interlinkages or synergies (see Sections 3 and 4.1), our analysis points to several challenges in realizing them. First, SFM, FLEGT, and REDD+ are usually disconnected approaches or regimes under different global proponents and their key policy documents do not cross-reference. Hence, separate guidance, requirements, and reporting formats prevail. Second, the issue of interlinkages or synergies is still a relatively new issue at the global level and it has not yet filtered down to the lower levels of governance (see also $[100,101]$ ). Third, there is limited communication between the main actors of SFM, FLEGT, and REDD+ at global and national/subnational levels. Fourth, there is a lack of resources and defined financial mechanisms for efforts to maximize synergies among the three at global and national/subnational levels $[16,100,101])$. Fifth, beyond the environmental domain, the World Trade Organization's global trade policies have created constraints on the advancement of goals under multilateral environmental agreements [58], and it is recognized that the effectiveness of SFM, FLEGT and REDD+ can be impacted by other sectoral policies, such as agriculture [102].

\subsection{Strategies to Manage the Interlinkages}

The authors propose three approaches to managing the interlinkages revealed in this study. First, awareness of the interlinkages could be greatly enhanced were such knowledge (of the presence of synergies and benefits) produced and communicated at the global level through a joint effort by SFM, FLEGT, and REDD+ constituents. Such joint interplay management [58] could, for example, be initiated by the European Commission and the UNFCCC secretariat, or by programs supporting REDD+ implementation, such as UN-REDD and the Forest Carbon Partnership Facility (FCPF) of the World Bank. Eventually, collaboration could, for example, be organized in the form of annual informal meetings during UNFCCC COP negotiations. For instance, exploring opportunities for synergistic activities and increasing coordination among the secretariats of the three Rio conventions (UNFCCC, Convention on Biological Diversity, and UN Convention to Combat Desertification) at the global level is enhanced through an informal forum called the Joint Liaison Group [103]. A similar arrangement at the global level could promote the awareness and benefits of the interlinkages among SFM, FLEGT, and REDD+. Ultimately, a cross-cutting work program should be developed to ensure that the activities, objectives, and policy tools of SFM, FLEGT, and REDD+ are complementary and mutually supportive. 
Second, efforts to maximize synergies and minimize trade-offs at the global level could also take place without a conscious joint effort by SFM, FLEGT, and REDD+ constituents. Such unilateral interplay management [58] is already being undertaken by the EU, promoting the interlinkages between FLEGT and REDD+ as early as in the negotiation phase of VPAs. Also, the UNFCCC secretariat, UN-REDD, the FAO FLEGT program and the World Bank FCPF could produce and disseminate communication products on SFM, FLEGT, and REDD+ interlinkages. Furthermore, the UNFF Secretariat could produce communication products on how FLEGT and REDD+ can interlink with SFM. At the 6th World Forest Week in Rome in July 2018, UN-REDD and FAO FLEGT organized an interactive panel discussion amongst government, private sector, and civil society representatives to explore and communicate interlinkages between FLEGT and REDD+ and the benefits of coordinating activities. The panel was useful in raising awareness of the benefits of linking REDD+ with FLEGT. The focus should be more on how to scale up these linkages in practice.

Third, although the scope of this study is at the global level, synergies can also be managed at lower levels of governance. For example, autonomous management [58] of SFM, FLEGT, and REDD+ interlinkages can take place at national and regional levels. This could be facilitated by individual actors, such as national/international non-governmental organizations (e.g., WWF, IUCN). For instance, IUCN conducted a study in Cameroon in 2014 and organized a stakeholder workshop to enhance the understanding and dialogue about FLEGT and REDD+ interlinkages.

Finally, implementers of SFM, FLEGT, and REDD+ should be cognizant of and leverage the political (and potentially financial) momentum brought about by recent international agreements to advance the agendas of and realize the interlinkages among SFM, FLEGT, and REDD+. Examples of such international agreements with strong consideration of policy coherence are the SDG 17.14, the UNSPF Global Forest Goals 5.3 and 6.3, and the Paris Agreement. Moreover, political and financial commitments associated with the New York Declaration on Forest and the Bonn Challenge to restore degraded forest and lands could contribute to realizing the interlinkages and advance the goals of SFM, FLEGT, and REDD+. Thus, this study provides a timely and relevant contribution to the understanding in developed and developing countries alike of strengthening policy coherence among forest-related policies. This could contribute to efforts to enhance the effectiveness of SFM, FLEGT, and REDD+ and strengthen policy coherence for sustainable development.

\section{Conclusions and Recommendations}

This study has demonstrated how a holistic concept of SFM can broadly interlink with FLEGT and REDD+ at a global policy level. Our findings revealed several interlinkages among SFM, FLEGT, and REDD+. The main interlinkages include forest information gathering, storage, and dissemination, securing rights for local communities, building stakeholders' capacity, driving reforms of legal frameworks, monitoring and evaluation, ensuring local benefits and wellbeing, establishing the enabling conditions of SFM, and addressing drivers of forest degradation. In terms of differences, FLEGT could mainly contribute to forest production, while REDD+ could maintain and extend forest cover, conserve biodiversity, and facilitate forest rehabilitation. Therefore, increased coordination in relation to the planning, implementation, and monitoring of SFM, FLEGT, and REDD+ is required to enable them to effectively contribute to SDGs.

SFM, FLEGT, and REDD+ interlinkages could be enhanced (i) through a joint effort by SFM, FLEGT, and REDD+ constituents, (ii) unilaterally without a conscious joint effort by the three, and (iii) through autonomous management at national and regional levels by individual actors, such as non-governmental organizations. To that end, four recommendations can be made that could catalyze progress toward SFM through strengthened forest policy coherence: 
1. SFM constituents at various levels should utilize and leverage FLEGT and REDD+ to achieve the sustainable management of tropical forests. This is in line with recent international commitments to strengthen policy coherence.

2. Greater coherence and coordination between SFM, FLEGT, and REDD+ constituents at the global level, such as the European Commission, the UNFCCC secretariat, and UN-REDD, would deliver a greater focus on rights, sustainable development, policy coherence, and poverty eradication. A cross-cutting work program is needed to ensure that the activities, objectives, and policy tools of SFM, FLEGT, and REDD+ are complementary and mutually supportive.

3. Individual actors, such as governments, international organizations, and civil society organizations, could pursue autonomous management of the interlinkages at regional and national levels.

4. Country-level analyses-including national FLEGT and REDD+ policy documentation, such as VPAs and REDD+ strategies—should be implemented to explore more specifically how FLEGT and REDD+ can interlink with SFM at national levels. Here, opportunities to manage interlinkages for forest policy coherence could also arise through national forest programs.

Finally, this study has revealed further research needs. For instance: How do FLEGT and REDD+ interlink with SFM at the national/subnational level implementation of the processes? What other important factors or policies contribute to the SFM sub-topics and influence the interlinkages, and how? How can SFM initiatives add value to the implementation of FLEGT and REDD+ processes?

Author Contributions: Y.T.T., M.C., and J.v.B. conceived the research; Y.T.T., M.C., and J.v.B. designed the methodological approach; M.C. performed the content analysis; M.C. and Y.T.T. analyzed the data; M.C. and Y.T.T. wrote the paper; Y.T.T. and J.v.B. revised the draft manuscript.

Funding: The research leading to the results presented in this paper has received funding from the Federal Republic of Germany under agreement Forest 2015-4 "SFM approaches to foster FLEGT and REDD+ interactions (SAFARI)".

Acknowledgments: This article benefited from the comments and insights provided by European Forest Institute (EFI) colleagues from EU FLEGT Facility - Alexander Hinrichs and Pheakkdey Nguon. The content of this paper reflects only the authors' views and neither the implementing organizations (EFI, the University of Hamburg, and the University of Leuven), nor the funding organization (BMEL) are liable for any use or interpretation that may be made of the information contained therein.

Conflicts of Interest: The authors declare no conflict of interest. The funder had no role in the design of the study; in the collection of, analyses, or interpretation of data; in the writing of the manuscript or in the decision to publish the results.

\section{Appendix A}

Table A1. Framework of seven thematic elements of SFM and sub-topics, including definitions.

\begin{tabular}{|c|c|}
\hline 1. Extent of forest resources & $\begin{array}{l}\text { The extent of forest resources is the first measure of SFM. It relates to the overall goal of } \\
\text { maintaining adequate forest resources-of various forest types and characteristics, } \\
\text { including other wooded land and trees outside forests- to support the social, } \\
\text { economic, and environmental objectives related to forests and forestry within a country } \\
\text { or region. [104] }\end{array}$ \\
\hline 1.1 Inventory and data & $\begin{array}{l}\text { Monitoring and estimating the extent of forest resources and changes therein, } \\
\text { including forest carbon stocks. }\end{array}$ \\
\hline 1.2 Afforestation and reforestation & $\begin{array}{l}\text { Planting of forest on previously non-forested or forested land, which leads to, } \\
\text { for example, the enhancement of forest carbon stocks. }\end{array}$ \\
\hline 1.3 Deforestation & Loss of forest cover. \\
\hline 2. Forest biological diversity & $\begin{array}{l}\text { Biological diversity encompasses the variety of existing life forms, the ecological roles } \\
\text { they perform, and the genetic diversity they contain. In forests, biological diversity } \\
\text { allows species to evolve and dynamically adapt to changing environmental conditions, } \\
\text { to maintain the potential for tree breeding and improvement and to support their } \\
\text { ecosystem functions. [104] }\end{array}$ \\
\hline 2.1 Biodiversity & Forest biodiversity in general terms, including at the level of ecosystems and species. \\
\hline 2.2 Biodiversity (genetic) & Conservation and use of genetic diversity of forests. \\
\hline 2.3 Protected areas & Protection/conservation of forests designated for this purpose. \\
\hline
\end{tabular}


Table A1. Cont.

3. Forest health and vitality

3.1 Natural disturbances and forest resilience

3.2 Forest degradation

3.3 Rehabilitation/restoration

4. Productive functions of forest resource

4.1 Forest productivity

4.2 Accounting

4.3 Forest product traceability systems

5. Protective functions of forest resources

5.1 Carbon and climate change mitigation

5.2 Climate change adaptation

5.3 Desertification and land degradation

5.4 Soil and water

6. Socioeconomic functions of forests

6.1 Economic development

6.2 Legality/illegality in production, processing, and trade

6.3 Local benefit and wellbeing

6.4 Resource rights

6.5 Traditional knowledge and use

6.6 Public participation

7. Legal, policy, and institutional framework

7.2 Country-level legal, policy, and institutional frameworks

7.3 Independent compliance schemes
Forests are subject to a variety of disturbances (e.g., fire, drought, disease outbreaks) that are themselves strongly influenced by climate. Climate change is expected to further affect forests' susceptibility to disturbances. All this can influence the composition, structure, and functions of forests and have impacts on the social, economic, and environmental dimensions of forestry. [104]

Natural disturbances to forests, such as alien species, fire, pests, and disease, and the resilience of forests to natural disturbances and the impacts of climate change. Loss of forest carbon stocks, which does not qualify as deforestation.

Efforts to rehabilitate/restore degraded forests

Forests, other wooded land, and trees outside forests provide a wide range of wood and non-wood forest products. The element indicates the economic and social utility of forest resources to national economies and forest-dependent local communities, and reflects the wish to maintain an ample and valuable supply of primary forest products, while at the same time ensuring that production and harvesting are sustainable and do not compromise the management options of future generations for productive or other functions of forests. [104]

Productivity of timber and non-timber resources, and associated management practices.

Timber and non-timber (e.g., biodiversity and carbon) data in the production, use, and trade in forest products.

Tracking of supply chains of forest products.

The world's forests have many protective functions-some local and some global, including protection of soils from wind and water erosion-and they can play a key role in climate change mitigation and adaptation. [104]

The role that forests and carbon stored in forests play in climate change and climate change mitigation.

The role that forests play in climate change adaptation. The role of forests in preventing desertification and land degradation. Forests' protective functions for soil and water.

Forests provide a wide variety of social and economic benefits, ranging from easily quantified economic values associated with forest products, to less tangible services and contributions to society. [104]

Economic growth, industrial wood production, processing, and related trade and employment.

Legality and illegality in the production and processing of and trade in wood.

Poverty reduction, livelihoods, healthcare and welfare of local, forest-dependent populations, in the context of benefits from forests to them. Rights to land and its resources.

Traditional/indigenous knowledge, management, and use of forest resources. Inclusiveness in decision-making and implementation in the context of forests.

The national legal, policy, and institutional framework related to forests constitutes the fundamental basis for SFM. National forest programs provide an internationally agreed framework that many countries use for the development and implementation of national forest-related policies and international commitments. The effective development and implementation of forest policy depends on the institutional capacity of national and subnational forest agencies. [104]

The transfer of finance, knowledge, technology, and other capacity in the context of forests.

National-level governance and policy, legal, or institutional frameworks for SFM.

Independent compliance schemes in the context of forests, such as sustainability certification, legality verification, and independent review processes.

\section{References}

1. Innes, J.; Tikina, A. Sustainable Forest Management: From Concept to Practice; Routledge: Abingdon, UK, 2016.

2. Rayner, J.; Buck, A.; Katila, P. (Eds.) IUFRO World Series Volume 28. In Embracing Complexity: Meeting the Challenges of International Forest Governance; IUFRO: Vienna, Austria, 2010; ISBN 9783902762016.

3. European Commission. Communication from the Commission to the Council and the European Parliament. Forest Law Enforcement, Governance and Trade (FLEGT). Proposal for an EU Action Plan; European Commission: Brussels, Belgium, 2003.

4. Forest Carbon Partnership Facility. FCPF Carbon Fund Methodological Framework. Revised Final. 22 June 2016. Available online: https://www.forestcarbonpartnership.org/sites/fcp/files/2016/July/ FCPFCarbonFundMethodologicalFrameworkrevised2016.pdf (accessed on 17 December 2018).

5. UN-REDD. UN-REDD Programme Stategic Framework 2016-2020; UN-REDD: Washington, DC, USA, 2015. 
6. Seymour, F.; Busch, J. Why Forests? Why Now? Center for Global Development: Washington, DC, USA, 2016; ISBN 9781933286853.

7. Fletcher, R.; Dressler, W.; Büscher, B.; Anderson, Z.R. Questioning REDD+ and the future of market-based conservation. Conserv. Biol. 2016, 30, 673-675. [CrossRef] [PubMed]

8. Rebecca, L. Rutta, Rodd Myers, Sabaheta Ramcilovic-Suominen, C.M. FLEGT: Another 'forestry fad'? Environ. Sci. Policy 2018, 89, 266-272. [CrossRef]

9. Hansen, C.P.; Rutt, R.; Acheampong, E. 'Experimental' or business as usual? Implementing the European Union Forest Law Enforcement, Governance and Trade (FLEGT) Voluntary Partnership Agreement in Ghana. For. Policy Econ. 2018, 96, 75-82. [CrossRef]

10. Hein, J.; Guarin, A.; Frommé, E.; Pauw, P. Deforestation and the Paris climate agreement: An assessment of REDD+ in the national climate action plans. For. Policy Econ. 2018, 90, 7-11. [CrossRef]

11. TEREAS; S-for-S; TopPerspective. Evaluation of the EU FLEGT Action Plan 2004-2014. Final Report (Volume 1); 2016. Available online: https://ec.europa.eu/europeaid/sites/devco/files/report-flegt-evaluation.pdf (accessed on 17 December 2018).

12. European Court of Auditors. EU Support to Timber-Producing Countries under the FLEGT Action Plan; Special Report No 13/2015; Publications Office of the European Union: Luxembourg, Luxembourg, 2015; p. 48.

13. European Council. Council Conclusions. Forest Law Enforcement, Governance and Trade; Council of the European Union: Brussels, Belgium, 2016.

14. European Parliament Committee on the Environment Public Health and Food Safety. Draft Opinion of the Committee on the Environment, Public Health and Food Safety for the Committee on Development on Transparent and Accountable Management of Natural Resources in Developing Countries: The Case of Forests; 2018. Available online: https://slidelegend.com/en-en-draft-opinion-european-parliament_ 5a9c7c381723ddfd5622972f.html (accessed on 17 December 2018).

15. Bastos Lima, M.G.; Kissinger, G.; Visseren-Hamakers, I.J.; Braña-Varela, J.; Gupta, A. The Sustainable Development Goals and REDD+: Assessing institutional interactions and the pursuit of synergies. Int. Environ. Agreem. Politics Law Econ. 2017, 17, 589-606. [CrossRef]

16. Tegegne, Y.T. FLEGT and REDD+ Synergies and Impacts in the Congo Basin: Lessons for Global Forest Governance; Academic Dissertation for the Dr. Sc. (Agric.\&For.) Degree; Viikki Tropical Resources Institute (VITRI): Helsinki, Finland, 2016; ISBN 978-951-51-2816-4.

17. Eikermann, A. Forests in International Law; Springer International Publishing: Cham, Switzerland, 2015; ISBN 978-3-319-14949-3.

18. Gupta, A.; Pistorius, T.; Vijge, M.J. Managing fragmentation in global environmental governance: The REDD+ Partnership as bridge organization. Int. Environ. Agreem. Politics Law Econ. 2016, 16, 355-374. [CrossRef]

19. Broekhoven, G.; Wit, M. (Eds.) Linking FLEGT and REDD+ to Improve Forest Governance; Tropenbos International: Wageningen, The Netherlands, 2014; ISBN 9789051131161.

20. Hajjar, R. Advancing small-scale forestry under FLEGT and REDD in Ghana. For. Policy Econ. 2015, 58, 12-20. [CrossRef]

21. Luttrell, C.; Fripp, E. Lessons from Voluntary Partnership Agreements for REDD+ Benefit Sharing; Center for International Forestry Research (CIFOR): Bogor, Indonesia, 2015.

22. Marfo, E.; Danso, E.; Nketiah, S.K. Analysis of Linkages and Opportunities for Synergies between FLEGT, REDD and National Forest Programme in Ghana; Tropenbos International Ghana: Wageningen, The Netherlands, 2013; ISBN 9789051131130.

23. Ochieng, R.M.; Visseren-Hamakers, I.J.; Nketiah, K.S. Interaction between the FLEGT-VPA and REDD+ in Ghana: Recommendations for interaction management. For. Policy Econ. 2013, 32, 32-39. [CrossRef]

24. Tegegne, Y.T.T.; Ochieng, R.M.M.; Visseren-Hamakers, I.J.J.; Lindner, M.; Fobissie, K.B.B. Comparative analysis of the Interactions between the FLEGT and REDD+ regimes in Cameroon and the Republic of Congo. Int. For. Rev. 2014, 16, 602-614. [CrossRef]

25. Proforest. Linking FLEGT and REDD+; Briefing Note No. 3; 2014. Available online: https:/ /redd.unfccc.int/ uploads/2_87_redd_20150619_eureddfacility_linking_flegt_and_redd_2B.pdf (accessed on 18 December 2018).

26. Swamy, L.; Drazen, E.; Johnson, W.R.; Bukoski, J.J. The future of tropical forests under the United Nations Sustainable Development Goals. J. Sustain. For. 2017, 37, 221-256. [CrossRef] 
27. FAO. The State of the World's Forests-Forest Pathaways to Sustainable Development; FAO: Rome, Italy, 2018; ISBN 9789251305614.

28. McDermott, C.L.; Carroll, A.O.; Wood, P. International Forest Policy-The Instruments, Agreements and Processes That Shape It; 2007. Available online: https://www.un.org/esa/forests/pdf/publications/Intl_Forest_ Policy_instruments_agreements.pdf (accessed on 18 December 2018).

29. Cosslett, C.E. Understanding the Potential Impacts of REDD+ on the Financing and Achievement of Sustainable Forest Management; A Report Prepared for the Secretariat of the United Nations Forum on Forests (UNFFS). Environment Strategies International, LLC: 2013. Available online: https: / pdfs.semanticscholar.org/d19e/8f402c09dea25fb1ae3b1f8f46a69472c6c8.pdf?_ga=2.73279507. 1808868653.1545118513-2080750717.1545118513 (accessed on 18 December 2018).

30. Singer, B. Financing sustainable forest management in developing countries: The case for a holistic approach. Int. For. Rev. 2016, 18, 96-109. [CrossRef]

31. United Nations Forum on Forests. Report on the Eleventh Session (19 April 2013 and 4 to 15 May 2015); United Nations: New York, USA, 2015.

32. United Nations. Non-Legally Binding Authoritative Statement of Principles for a Global Consensus on the Management, Conservation and Sustainable Development of All Types of Forests; 1992. Available online: http:/ / www.un-documents.net/for-prin.htm (accessed on 17 December 2018).

33. Morgenstern, E.K. The origin and early application of the principle of sustainable forest management. For. Chron. 2007, 83, 485-489. [CrossRef]

34. Wiersum, K. 200 years of sustainability in forestry: Lessons from history. Environ. Manag. 1995, 19, $321-329$. [CrossRef]

35. United Nations Forum on Forests. Report of the Seventh Session (24 February 2006 and 16 to 27 April 2007); United Nations: New York, USA, 2007.

36. Wilkie, M.L.; Holmgren, P.; Castañeda, F. Sustainable Forest Management and the Ecosystem Approach: Two Concepts, One Goal; Rome, Italy, 2003. Available online: http://www.fao.org/forestry/64170905522127db12a324c6991d0a53571fa.pdf (accessed on 18 December 2018).

37. Lanly, J.-P. Sustainable forest management: Lessons of history and recent developments. Unasylva 1995, 46, $38-45$.

38. CICI. International Conference on the Contribution of Criteria and Indicators for Sustainable Forest Management: The Way Forward; CICI: Guatemala City, Guatemala, 2003.

39. COFO. Report of the Sixteenth Session of the Committee on Forestry; COFO: Rome, Italy, 2003.

40. FAO/ITTO. Expert Consultation on Criteria and Indicators for Sustainable Forest Management; FAO/ITTO: Cebu City, Philippines, 2004.

41. CPF. Collaborative Partnership on Forests Task Force on Streamlining Forest-Related Reporting. Information Framework for Forest Reporting; 2004. Available online: http:/ / www.fao.org/forestry/3089004dc00a5cb6c13b5fc17b9039ea47b0f4.pdf (accessed on 18 December 2018).

42. Young, M.A. Climate Change Law and Regime Interaction. Carbon Clim. Law Rev. 2011, 5, 147-157. [CrossRef]

43. Krasner, S.D. Structural Causes and Regime Consequences: Regimes as Intervening Variables. Int. Organ. 1982, 36, 185-205. [CrossRef]

44. Keohane, R.O.; Haas, P.M.; Levy, M. The effectiveness of International Environmental Institutions. In Institutions for the Earth: Sources of Effective Environmental Protection; Haas, P.M., Keohane, R.O., Levy, M., Eds.; MIT Press: Cambridge, MA, USA, 1993.

45. Oberthür, S.; Gehring, T. (Eds.) Institutional Interaction in Global Environmental Governance: Synergy and Conflict among International and EU Policies; MIT Press: London, UK, 2006.

46. Visseren-Hamakers, I.J.; McDermott, C.L.; Vijge, M.J.; Cashore, B. Trade-offs, co-benefits and safeguards: Current debates on the breadth of REDD+. Curr. Opin. Environ. Sustain. 2012, 4, 646-653. [CrossRef]

47. Gehring, T.; Oberthür, S. The causal mechanisms of interaction between international institutions. Eur. J. Int. Relations 2009, 15, 125-156. [CrossRef]

48. Böhmelt, T.; Spilker, G. The Interaction of International Institutions from a Social Network Perspective. Int. Environ. Agreem. Politics Law Econ. 2016, 1-32. [CrossRef]

49. Biermann, F.; Pattberg, P.; van Asselt, H.; Zelli, F. The Fragmentation of Global Governance Architectures: A Framework for Analysis. Glob. Environ. Politics 2009, 9, 14-40. [CrossRef] 
50. Van Asselt, H. The Fragmentation of Global Climate Governance: Consequences and Management of Regime Interactions; VU University Amsterdam: Amsterdam, The Netherlands, 2013.

51. Wolfslehner, B.; Vacik, H.; Lexer, M.J. Application of the analytic network process in multi-criteria analysis of sustainable forest management. For. Ecol. Manag. 2005, 207, 157-170. [CrossRef]

52. Jalilova, G.; Khadka, C.; Vacik, H. Developing criteria and indicators for evaluating sustainable forest management: A case study in Kyrgyzstan. For. Policy Econ. 2012, 21, 32-43. [CrossRef]

53. ITTO. Revised ITTO Criteria and Indicators for the Sustainable Management of Tropical Forests; ITTO: Yokohama, Jaan, 2016; ISBN 9784865070286.

54. Kleinschmit, D.; Mansourian, S.; Wildburger, C.; Purret, A. (Eds.) Illegal Logging and Related Timber Trade-Dimensions, Drivers, Impacts and Responses. A Global Scientific Rapid Response Assessment Report; IUFRO: Vienna, Austria, 2016; Volume 35, ISBN 3901347240.

55. Seppälä, R.; Buck, A.; Katila, P. (Eds.) Adaptation of Forests and People to Climate Change-A Global Assessment Report; IUFRO: Vienna, Austria, 2009.

56. United Nations. Forest Resources Assessment 2020 (FRA2020), Enhanced and Streamlined International Reporting; Note by the Secretariat; United Nations: 2017. Available online: http://www.fao.org/3/a-mu039e.pdf (accessed on 18 December 2018).

57. Corning, P.A. "The synergism hypothesis": On the concept of synergy and its role in the evolution of complex systems. J. Soc. Evol. Syst. 1998, 21, 133-172. [CrossRef]

58. Oberthür, S. Interplay management: Enhancing environmental policy integration among international institutions. Int. Environ. Agreem. Politics Law Econ. 2009, 9, 371-391. [CrossRef]

59. Savaresi, A. The Role of REDD in the Harmonisation of Overlapping International Obligations. In Climate Change and the Law; Hollo, E.J., Kulovesi, K., Mehling, M., Eds.; Springer: Dordrecht, The Netherlands, 2013; pp. 391-418, ISBN 9789400754409.

60. Chambers, W.B. Interlinkages and the Effectiveness of Multilateral Environmental Agreements; United Nations University Press: Hong Kong, China, 2008; ISBN 9789280811490.

61. European Council Council Conclusions. Forest Law Enforcement, Governance and Trade (FLEGT). Off. J. Eur. Union 2003. [CrossRef]

62. European Commission. FLEGT Briefing Notes No 1-8; 2007. Available online: https://ec.europa.eu/ europeaid/search/site/FLEGT\%20Briefing\%20Notes-Briefing\%20Note_en (accessed on 18 December 2018).

63. UNFCCC. Report of the Conference of the Parties on Its Thirteenth Session, Held in Bali from 3 to 15 December 2007. Addendum. Part Two: Action Taken by the Conference of the Parties at Its Thirteenth Session; 2008. Available online: https:/ / unfccc.int/resource/docs/2007/cop13/eng/06a01.pdf (accessed on 18 December 2018).

64. UNFCCC. Report of the Conference of the Parties on Its Fifteenth Session, Held in Copenhagen from 7 to 19 December 2009. Addendum. Part Two: Action Taken by the Conference of the Parties at Its Fifteenth Session; 2010. Available online: https:/ / unfccc.int/resource/docs/2009/cop15/eng/11a01.pdf (accessed on 18 December 2018).

65. UNFCCC. Report of the Conference of the Parties on Its Sixteenth Session, Held in Cancun from 29 November to 10 December 2010. Addendum. Part Two: Action Taken by the Conference of the Parties at Its Sixteenth Session; 2011. Available online: https://unfccc.int/sites/default/files/resource/docs/2010/cop16/eng/07a01.pdf (accessed on 18 December 2018).

66. UNFCCC. Report of the Conference of the Parties on Its Nineteenth Session, Held in Warsaw from 11 to 23 November 2013. Addendum. Part Two: Action Taken by the Conference of the Parties at Its Nineteenth Session; 2014. Available online: https://unfccc.int/sites/default/files/resource/docs/2013/cop19/eng/10a01.pdf (accessed on 18 December 2018).

67. UNFCCC. Report of the Conference of the Parties on Its Twenty-First Session, Held in Paris from 30 November to 13 December 2015. Addendum. Part Two: Action Taken by the Conference of the Parties at Its Twenty-First Session; 2016. Available online: https://unfccc.int/resource/docs/2015/cop21/eng/10.pdf (accessed on 18 December 2018).

68. Green Climate Fund. Terms of Reference for the Pilot Programme for REDD+Results-Based Payments; 2017. Available online: https:/ / www.greenclimate.fund/documents/20182/1203466/Terms_of_reference_for_ the_pilot_programme_for_REDD_results-based_payments.pdf/e26651fc-e216-c8b0-55a1-8eea16a90f39 (accessed on 18 December 2018).

69. Owen, G.T. Qualitative Methods in Higher Education Policy Analysis: Using Interviews and Document Analysis. Qual. Rep. 2014, 19, 1-19. 
70. Elias, P. Logging and the Law: How the U.S. Lacey Act Helps Reduce Illegal Logging in the Tropics; Union of Concerned Scientists: Cambridge, UK, 2012.

71. Schneibel, A.; Frantz, D.; Röder, A.; Stellmes, M.; Fischer, K.; Hill, J. Using annual landsat time series for the detection of dry forest degradation processes in South-Central Angola. Remote Sens. 2017, 9, 905. [CrossRef]

72. Van Hensbergen, B. Forest Concessions_Past Present and Future? Forestry and Institutions Working Paper 36; FAO: Rome, Italy, 2016.

73. Nasi, R.; Billand, A.; van Vliet, N. Managing for timber and biodiversity in the Congo Basin. For. Ecol. Manag. 2012, 268, 103-111. [CrossRef]

74. Kissinger, G.; Herold, M.; De Sy, V. Drivers of Deforestation and Forest Degradation: A Synthesis Report for REDD+ Policymakers; Lexeme Consulting: Vancouver, BC, Canada, 2012.

75. European Commission. A Timber Legality Assurance System; FLEGT Briefing Notes. No. 3; 2007. Available online: https:/ / ec.europa.eu/europeaid/sites/devco/files/publication-flegt-briefing-note-series2007-3-200703_en.pdf (accessed on 18 December 2018).

76. Ndjondo, M.; Gourlet-Fleury, S.; Manlay, R.J.; Engone Obiang, N.L.; Ngomanda, A.; Romero, C.; Claeys, F.; Picard, N. Opportunity costs of carbon sequestration in a forest concession in central Africa. Carbon Balanc. Manag. 2014, 9, 1-13. [CrossRef] [PubMed]

77. Nitcheu Tchiadje, S.; Sonwa, D.J.; Nkongmeneck, B.A.; Cerbonney, L.; Sufo Kankeu, R. Preliminary estimation of carbon stock in a logging concession with a forest management plan in East Cameroon. J. Sustain. For. 2016, 35, 355-368. [CrossRef]

78. Sasaki, N.; Chheng, K.; Ty, S. Managing production forests for timber production and carbon emission reductions under the REDD+ scheme. Environ. Sci. Policy 2012, 23, 35-44. [CrossRef]

79. Pearson, T.R.H.; Brown, S.; Murray, L.; Sidman, G. Greenhouse gas emissions from tropical forest degradation: An underestimated source. Carbon Balanc. Manag. 2017, 12, 1-11. [CrossRef] [PubMed]

80. UNCCD. REDD+ and Desertification; UNCCD Thematic Factsheets Series No. 7; UNCCD Secretariat: Bonn, Germany, 2013.

81. Asen, A.; Savenije, H.; Schmidt, F. (Eds.) Good Business: Making Private Investments Work for Tropical Forests; Tropenbos International: Wageningen, The Netherlands, 2012; ISBN 9789051131116.

82. Watson, C.; Brickell, E.; McFarland, W. Integrating REDD+ into a Green Economy Transition-Opportunities and Challenges; ODI: London, UK, 2013.

83. European Commission. FLEGT Briefing Notes; No. 1. What is FLEGT?. 2007. Available online: https: / / ec.europa.eu/europeaid/sites / devco / files / publication-flegt-briefing-note-1-200404_en.pdf (accessed on 18 December 2018).

84. European Commission. FLEGT Briefing Notes; No. 6. Voluntary Partnership Agreements. 2007. Available online: https:/ / ec.europa.eu/europeaid/sites/devco/files/publication-flegt-briefing-note-7200404_en.pdf (accessed on 18 December 2018).

85. Ravikumar, A.; Andersson, K.; Mwangi, E.; Guariguata, M.R.; Nasi, R. Towards more equitable terms of cooperation: Local people's contribution to commercial timber concessions. Int. For. Rev. 2012, 14, 157-176. [CrossRef]

86. World Bank. Rethinking Forest Partnerships and Benefit Sharing. Insights on Factors and Context That Make Collaborative Arrangements Work for Communities and Landowners; World Bank: Washington, DC, USA, 2009.

87. Strassburg, B.; Vira, B.; Mahanty, S.; Mansourian, S.; Martin, A.; Dawson, N.; Gross-Camp, N.; Latawiec, A. Social and economic considerations relevant to REDD+. In Understanding Relationships between Biodiversity, Carbon, Forests and People: The Key to Achieving REDD+ Objectives; Parotta, J., Wildburger, C., Mansourian, S., Eds.; IUFRO: Vienna, Austria, 2012.

88. United Nations Environmental Programme. Forests in a Changing Climate: A Sourcebook for Integrating REDD+ into Academic Programmes; UNEP: Nairobi, Kenya, 2014; ISBN 978-92-807-3392-1.

89. Awono, A.; Somorin, O.A.; Eba'a Atyi, R.; Levang, P. Tenure and participation in local REDD+ projects: Insights from southern Cameroon. Environ. Sci. Policy 2014, 35, 76-86. [CrossRef]

90. Sunderlin, W.D.; Larson, A.M.; Duchelle, A.E.; Resosudarmo, I.A.P.; Huynh, T.B.; Awono, A.; Dokken, T. How are REDD+ Proponents Addressing Tenure Problems? Evidence from Brazil, Cameroon, Tanzania, Indonesia, and Vietnam. World Dev. 2014, 55, 37-52. [CrossRef]

91. Karsenty, A.; Vogel, A.; Castell, F. "Carbon rights", REDD+ and payments for environmental services. Environ. Sci. Policy 2014, 35, 20-29. [CrossRef] 
92. Conservation International; Environmental Defense Fund; National Wildlife Federation; Rainforest Alliance; The Nature Conservancy; Union of Concerned Scientists. Clarifying the Role of Non-Carbon Benefits in REDD+; 2014. Available online: http://unfccc.int/resource/docs/2014/smsn/ngo/405.pdf (accessed on 18 December 2018).

93. Brack, D.; Léger, C. Exploring Credibility Gaps in Voluntary Partnership Agreements. A Review of Independent Monitoring Initiatives and Lessons to Learn; Global Witness Limited: London, UK, 2013.

94. Graham, K. Making REDD+Cross-Sectoral: Why, How, and What Are the Potential Socio-Economic Impacts? REDD-net programme: 2011. Available online: https://www.odi.org/sites/odi.org.uk/files/odi-assets/ publications-opinion-files /7287.pdf (accessed on 18 December 2018).

95. Wodschow, A.; Nathan, I.; Cerutti, P. Participation, public policy-making, and legitimacy in the EU Voluntary Partnership Agreement process: The Cameroon case. For. Policy Econ. 2016, 63, 1-10. [CrossRef]

96. Overdevest, C.; Zeitlin, J. Experimentalism in transnational forest governance: Implementing European Union Forest Law Enforcement, Governance and Trade (FLEGT) Voluntary Partnership Agreements in Indonesia and Ghana. Regul. Gov. 2017, 12, 64-87. [CrossRef]

97. Long, A. REDD+, adaptation, and sustainable forest management: Toward effective polycentric global forest governance. Trop. Conserv. Sci. 2013, 6, 384-408. [CrossRef]

98. De La Rochefordiere, A.; van Laake, P. Synergies between the TLAS and the National Forest Monitoring System. In Linking FLEGT and REDD+ to Improve Forest Governance; Broekhoven, G., Wit, M., Eds.; Tropenbos International: Wageningen, The Netherlands, 2014; pp. 155-163.

99. United Nations Economic and Social Council. United Nations Strategic Plan for Forests 2017-2030 and Quadrennial Programme of Work of the United Nations Forum on Forests for the Period 2017-2020; 2017. Available online: https:/ / documents-dds-ny.un.org/doc/UNDOC/GEN/N17/184/62/PDF/N1718462. pdf?OpenElement (accessed on 18 December 2018).

100. Duguma, L.A.; Minang, P.A.; Van Noordwijk, M. Climate change mitigation and adaptation in the land use sector: From complementarity to synergy. Environ. Manag. 2014, 54, 420-432. [CrossRef] [PubMed]

101. Locatelli, B.; Fedele, G.; Fayolle, V.; Baglee, A. Synergies between adaptation and mitigation in climate change finance. Int. J. Clim. Chang. Strateg. Manag. 2016, 8, 112-128. [CrossRef]

102. Dubé, Y.C.; Schmithüsen, F. Cross-Sectoral Policy Impacts between Forestry and Other Sectors; FAO Forestry Paper 142; FAO: Rome, Italy, 2003.

103. UNFCCC; CBD; UNCCD. Terms of Reference and Modus Operandi for the Joint Liaison Group between the Three Rio Conventions; 2013. Available online: https:/ / www.cbd.int/cooperation/doc/jlg-modus-operandi-en.pdf (accessed on 18 December 2018).

104. FAO. Global Forest Resources Assessment 2010-Main Report; FAO: Rome, Italy, 2010. 